\title{
Performance Evaluation of Indonesian Banks and Foreign Banks Operating in Indonesia Related to Classification of Capital
}

\author{
Sugiarto \\ Sekolah Tinggi Ilmu Ekonomi Wiyatamandala, Department of Management, Jakarta, Indonesia \\ sugiarto@wiyatamandala.ac.id
}

\begin{abstract}
This study was undertaken to prove the public perception that bigger banks are more difficult to bankrupt than smaller banks through performance evaluation of Indonesian banks and foreign banks operating in Indonesia related to classification of capital. The study was conducted using secondary data obtained from Info bank. Overall there were 120 banks evaluated, either local banks belonging to the various classifications of books as well as foreign banks operating in Indonesia. As the research variables are the bank's core capital, Non-Performing Loan (NPL) and Net Interest Margin (NIM). Grouping of banks has done according to the rules of Indonesia Bank (BI) on commercial banks business activities (books). Tests were performed using descriptive statistics, One Way ANOVA and Post Hoc Test. The results obtained indicate that banks with more capital and also foreign banks are not more able to reduce their credit risk and also not show better ability to produce gains than local banks with smaller capital. The findings of this study indicate the success of the Indonesia Bank (BI) as the Indonesian banking regulatory authority to equate the performance of banks operating in Indonesia.
\end{abstract}

Keywords- Bank's Performance, Core capital, NonPerforming Loans, Net Interest Margin

\section{INTRODUCTION}

As an intermediary institution, the basic function of a bank is to connect those who have excess funds to those who need funds. Parties that have excess funds, put their money in the bank with some purpose as ever for security reasons until consideration earn interest income. Parties who need of funds apply for a loan to banks also with number of considerations, ranging from cost of fund up to consideration of the tax shield.

In determining the selected bank, the parties who have excess funds consider some reasons, the most important one is the safety of their funds. Most people do not object to obtain lower interest income as far as the security of its funding is guaranteed. On the other hand it is also found people who prefer to earn higher interest although they get less guarantees of their funds.

So far it is found a perception in the community that bigger banks are more difficult to bankrupt than smaller banks, therefore it is considered that the bigger banks are safer to save money compared to smaller banks. Public confidence to certain bank, impact on the amount of funds kept at that bank, which in turn affects the growth of bank capital.

Previous research used capital adequacy ratio as one of the key indicators of capital classification [1]. Capital adequacy ratio is one of the most significant current issues in banking which evaluate the amount of a bank's efficiency and stability. The Basel Capital Accord is an international standard for the calculation of capital adequacy ratios. The Accord recommends minimum capital adequacy ratios that banks should meet. Using minimum capital adequacy ratios causes promotion in stability and efficiency of the financial system by decreasing the likelihood of insolvency in banks. In the aftermath of the financial crisis, there have been efforts by regulatory authorities to make banks stronger. To accomplish this, governments across the developed world are enforcing strengthen their balance sheets by increasing capital, and if they cannot raise more capital, they are told to decrease the amount of risk assets (loans) on their books [1].

Associated with the bank's capital, in connection with the risk management policies of banks in Indonesia, Indonesia Bank (BI) as the Indonesian banking regulatory authority requires banks operating in Indonesia to maintain their capital adequacy to face all possibilities including on conditions that are not desired [2]. In this case, the bank's capital is regulated by banking authorities in Indonesia because of bank intermediation function. Most of the funds disbursed in the form of bank credit is a third party deposits. If the bank fails, the impact of bank failure could affect depositors, and can cause spillovers both domestic and international markets. Because the bank's role is so important, the minimum capital requirements should be regulated properly. Setting minimum capital aims to maintain customer confidence in the banking system. Indonesia Bank as the Indonesian banking regulatory authority stated that the banks operating in Indonesia are obliged to provide appropriate minimum capital related to their risk profile [3]. Banks in Indonesia should make the Internal Capital Adequacy Assessment Process (ICAAP). Indonesia Bank stated that banks operating in Indonesia are obliged to have a process for assessing overall capital adequacy associated with a risk profile and a strategy for maintaining the capital level [4]. Supervisors require banks to operate above the specified capital ratios and require banks to provide capital above the minimum threshold [5]. 
Growing perception in the community that the bigger banks go bankrupt more difficult than smaller banks, implicitly imply the view that bigger banks should have better performance than smaller banks. The indicators that are relevant to the performance of the banks are Non-Performing Loan (NPL), which represents the performance of the bank regarding the quality of bank assets and also an indicator of the ability of banks to manage their credit risk and Net Interest Margin (NIM), which represents the performance of banks in respect of bank efficiency.

Non-Performing Loan (NPL), is one of the key indicators to assess whether a bank is performing well or not. NPL is one of the indicators for bank credit risk. High NPL on the bank indicates a problem in the bank that if they do not immediately get a solution would jeopardize the bank's condition. With the higher NPL ratio of banks, the level of bank liquidity against third party funds will be lower. There are many factors that impact the bank NPL that can be classified into three groups, namely the bank internal factors, debtor factors and external factors. Regardless of any factors that cause high NPL, bank's inability to manage their NPL indicates the ability of bank management is not promising.

Net interest margin (NIM) is also one of the key indicators for the bank's performance as NIM indicates bank's ability to generate income from interest by looking at the banks' performance in lending. As an intermediary institution, banks are classified as lending institutions, so that the activity is closely related to the nature of credit, setting rules and procedures for granting credit, credit analysis, establishment of credit limits and credit security. The main objective of lending is for a profit, the pursuit of record profits should consider the security of the bank so that the bank remains trusted by the community. In turn the public trust have a multiplier effect that led to the sustainability of the banks.

On the condition that banks are having problems, the banking authority requires banks can solve their own problems with capital adequacy [6]. According to this, the Indonesian banking regulatory authority requires banks to have a capital adequacy in running the bank's operations included therein is able to overcome the conditions at the time were very bad [7]. As also stated by previous research [1], capital adequacy generally affects all entities. But as a term, it is most often used in discussing the position of firms in the financial section of the economy, and precisely, whether firms have sufficient capital to cover the risks that they confront. The greater the bank's capital, banks are more able to exit from crisis conditions. The greater the bank's capital, banks are more able to attract people to entrust their funds in the bank.

However, is the perception spread in the community that the bigger the bank, the better its performance in line with the facts?. This study was undertaken to prove the public perception through performance evaluation of Indonesian banks and foreign banks operating in Indonesia related to classification of capital.

\section{Methodology}

The study was conducted using secondary data obtained from the relevant source [8]. As the research variables are the bank's core capital, NPL and NIM. Grouping of banks has done according to the rules of Indonesia Bank (BI) on commercial banks business activities (books). In this research, there are four classifications related local banks core capital and one classification related foreign banks [8], namely:

- Bank with core capital of less than IDR 1 trillion (Book 1)

- Bank with core capital of IDR 1 trillion up to below IDR 5 trillion (Book 2)

- Bank with core capital of IDR 5 trillion up to below IDR 30 trillion (Book 3)

- Bank with core capital of more than IDR 30 trillion (Book 4)

- Foreign Banks

Bank's performance in the classification of the various books and foreign banks categories were evaluated with respect to bank's NIM and bank's NPL which in this case are used as indicators of the bank's performance. Tests were performed using descriptive statistics, One Way ANOVA and Post Hoc Test. Tests conducted on these two hypotheses:

\section{Hypotheses for variable NPL:}

Ho: There is no difference in the average NPL of local banks with the various classifications of books as well as foreign banks

Ha: At least there are differences in the average NPL of local banks with the various classifications of books and foreign banks

\section{Hypotheses for variable NIM:}

Ho: There is no difference in the average NIM of local banks with the various classifications of books as well as foreign banks

Ha: At least there are differences in the average NIM of local banks with the various classifications of books and foreign banks.

\section{RESULTS AND DISCUSSION}

Overall there were 120 banks evaluated, either local banks belonging to the various classifications of books as well as foreign banks operating in Indonesia.

TABLE I. DESCRIPTIVE STATISTICS OF NPL

\begin{tabular}{|l|c|c|c|c|c|}
\hline \multirow{2}{*}{} & $\mathbf{N}$ & Range & \multicolumn{2}{|c|}{ Mean } & $\begin{array}{c}\text { Std. } \\
\text { Deviation }\end{array}$ \\
\cline { 2 - 6 } & Statistic & Statistic & Statistic & Std. Error & Statistic \\
\hline Book_1 & 60 & 9.95 & 1.8045 & .24035 & 1.86175 \\
Book_2 & 35 & 7.45 & 2.1217 & .28475 & 1.68463 \\
Book_3 & 11 & 3.51 & 1.9000 & .27417 & .90933 \\
Book_4 & 4 & 2.46 & 1.6850 & .50408 & 1.00815 \\
B_Foreign & 10 & 4.87 & 1.3630 & .49717 & 1.57220 \\
& & & & & \\
\hline
\end{tabular}

Based on descriptive statistics of the NPL as stated in Table I, there are not seen any pattern according to the average of the 
NPL from different groups of banks. The average NPL of classified banks in Book $2(2.1217 \%)$ is seen higher than average NPL of classified banks in Book 1, Book 3, Book 4 and foreign banks. The average NPL of Foreign Banks (1.3630 $\%)$ is the lowest of all.

The highest NPL variations was found in banks which is classified in Book 1, while the lowest NPL Range obtained in banks which is classified in Book 4. Banks which is classified in book 3 has the lowest NPL standard deviation.

TABLE II. ANOVA OF NPL

\begin{tabular}{|l|c|c|c|c|c|}
\hline & $\begin{array}{c}\text { Sum of } \\
\text { Squares }\end{array}$ & df & $\begin{array}{c}\text { Mean } \\
\text { Square }\end{array}$ & F & Sig. \\
\hline Between Groups & 5.189 & 4 & 1.297 & .446 & .775 \\
Within Groups & 334.556 & 115 & 2.909 & & \\
Total & 339.745 & 119 & & & \\
\hline
\end{tabular}

Further testing using One Way ANOVA as stated in Table II, showed no significant differences were found on average NPL of all classifications bank book including foreign banks. Significance testing of 0.775 on the ANOVA states not enough evidence to reject the null hypothesis. Results of Post Hoc Test of NPL either using Tukey HSD test which is categorized as the most rigorous test and LSD test that has the loosest criteria for testing at the 0.05 significance level as stated in Table III are consistent with the One Way ANOVA finding. Thus it can be concluded that the average ability of local banks by various categories related to their core capital and foreign banks NPL performance was not significantly different at the 0.05 significance level. In accordance with the nominal amount of capital of each bank, it is possible that the average of nonperforming loans at each bank book will vary nominally, however, the test results prove that the average of nonperforming loans in the percentage did not differ significantly. Empirical data shows that banks with larger capital and also foreign banks are not more able to manage their NPL which representing credit risk than banks with less capital. The research results showed not found differences in the ability of banks with larger capital and foreign banks with banks with smaller capital in managing their credit risk. This research finding is consistent with findings of the previous research [9] stating that Risk Asset Ratio (RAR) does not have any significant relationship with CAR (capital adequacy ratio). Previous research [9] used capital adequacy ratio as a significant indicator of "safety and stability" for banks and depository institutions because they view capital as a guard or cushion for absorbing losses, while the Risk Asset Ratio evaluates the amount of a bank's total regulatory capital in relation to the amount of risk it is taking. The findings of this study indicate the success of the Indonesia Bank (BI) as the Indonesian banking regulatory authority to equate the performance of banks operating in Indonesia in managing their NPL.
TABLE III. POST HOC TEST OF NPL

\begin{tabular}{|c|c|c|c|c|}
\hline & (I) Book & (J) Book & \begin{tabular}{|c|} 
Mean \\
Difference (I- \\
$\mathbf{J})$
\end{tabular} & Sig. \\
\hline \multirow{20}{*}{$\begin{array}{l}\text { Tukey } \\
\text { HSD }\end{array}$} & \multirow[t]{4}{*}{1.00} & 2.00 & -.31721 & .906 \\
\hline & & 3.00 & -.09550 & 1.000 \\
\hline & & 4.00 & .11950 & 1.000 \\
\hline & & B_Foreign & .44150 & .942 \\
\hline & \multirow[t]{4}{*}{2.00} & 1.00 & .31721 & .906 \\
\hline & & 3.00 & .22171 & .996 \\
\hline & & 4.00 & .43671 & .989 \\
\hline & & B_Foreign & .75871 & .728 \\
\hline & \multirow[t]{4}{*}{3.00} & 1.00 & .09550 & 1.000 \\
\hline & & 2.00 & -.22171 & .996 \\
\hline & & 4.00 & .21500 & 1.000 \\
\hline & & B_Foreign & .53700 & .951 \\
\hline & \multirow[t]{4}{*}{4.00} & 1.00 & -.11950 & 1.000 \\
\hline & & 2.00 & -.43671 & .989 \\
\hline & & 3.00 & -.21500 & 1.000 \\
\hline & & B_Foreign & .32200 & .998 \\
\hline & \multirow[t]{4}{*}{ B_Foreign } & 1.00 & -.44150 & .942 \\
\hline & & 2.00 & -.75871 & .728 \\
\hline & & 3.00 & -.53700 & .951 \\
\hline & & 4.00 & -.32200 & .998 \\
\hline \multirow[t]{20}{*}{ LSD } & \multirow[t]{4}{*}{1.00} & 2.00 & -.31721 & 384 \\
\hline & & 3.00 & -.09550 & .865 \\
\hline & & 4.00 & .11950 & .892 \\
\hline & & B_Foreign & .44150 & 450 \\
\hline & \multirow[t]{4}{*}{2.00} & 1.00 & .31721 & 384 \\
\hline & & 3.00 & .22171 & .708 \\
\hline & & 4.00 & .43671 & .629 \\
\hline & & B_Foreign & .75871 & 217 \\
\hline & \multirow[t]{4}{*}{3.00} & 1.00 & .09550 & .865 \\
\hline & & 2.00 & -.22171 & .708 \\
\hline & & 4.00 & .21500 & 829 \\
\hline & & B_Foreign & .53700 & .473 \\
\hline & \multirow[t]{4}{*}{4.00} & 1.00 & -.11950 & .892 \\
\hline & & 2.00 & -.43671 & .629 \\
\hline & & 3.00 & -.21500 & .829 \\
\hline & & B_Foreign & .32200 & .750 \\
\hline & \multirow[t]{4}{*}{ B_Foreign } & 1.00 & -.44150 & 450 \\
\hline & & 2.00 & -.75871 & 217 \\
\hline & & 3.00 & -.53700 & 473 \\
\hline & & 4.00 & -.32200 & .750 \\
\hline
\end{tabular}

Based on descriptive statistics of the NIM as stated in Table $\mathrm{IV}$, there are not seen any pattern according to the average of the NIM from different groups of banks. The average NIM of banks that belong in Book 1 to Book 4 does not look so different, however the average NIM of Foreign Banks (2.8180 $\%$ ) stands out as the least of all the mean average NIM of banks in various books that were analyzed.

The highest NIM variation obtained at banks which is classified in Book 1, consistent with the information obtained from Range statistic. The analysis shows that banks classified as Foreign Banks has the lowest NIM standard deviation, while the lowest NIM Range obtained in banks belonging Book 4. 
TABLE VI. POST HOC TEST OF NIM

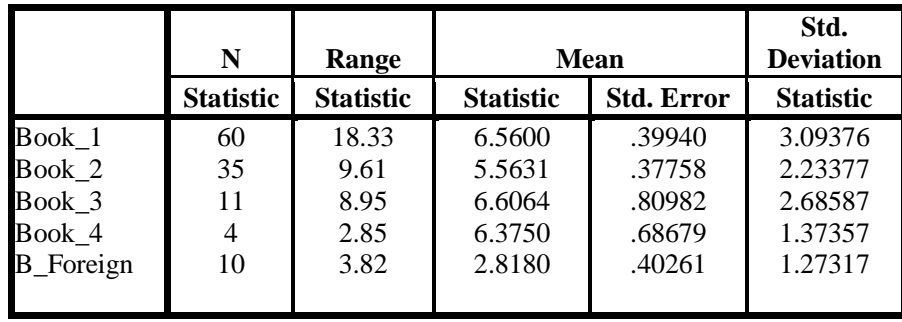

TABLE V. ANOVA OF NIM

\begin{tabular}{|l|c|c|c|c|c|}
\hline & $\begin{array}{c}\text { Sum of } \\
\text { Squares }\end{array}$ & df & $\begin{array}{c}\text { Mean } \\
\text { Square }\end{array}$ & F & Sig. \\
\hline Between Groups & 131.116 & 4 & 32.779 & 4.560 & .002 \\
Within Groups & 826.746 & 115 & 7.189 & & \\
Total & 957.862 & 119 & & & \\
\hline
\end{tabular}

Further testing using One way ANOVA as stated in Table $\mathrm{V}$, showed significant differences were found on average NIM of all classifications bank book including foreign banks. Significance testing of 0.002 in the ANOVA stated enough evidence to reject the null hypothesis. It can be concluded that at least there are differences in the average NIM on the banks belonging to the classification of different books. Results of Post Hoc Test of NIM either using Tukey HSD test and LSD test for testing at the 0.05 significance level as stated in Table VI, are consistent with the One Way ANOVA finding. Thus it can be concluded that the average ability of banks by various categories related core capital according to bank's NIM performance are significantly different at the 0.05 significance level. This research finding is consistent with findings of the previous research [9] which also provided evidence of positive relationship between Return on Equity (ROE), and Return on Asset (ROA) and capital adequacy ratio. The previous study [9], applying the ROA and ROE as proxies for bank profitability, as previous researcher was also regards the return on assets (ROA) ratio as a major indicator of a well-managed bank [10].

Post Hoc Test results using Tukey HSD states that the performance of the Foreign Bank in connection with NIM differ significantly from local banks which are classified in Book 1, Book 2 and Book 3, but did not differ significantly from local banks which is classified in Book 4. The performance of local banks' NIM did not show any significant difference.

Post Hoc Test results using LSD states that the performance of the Foreign Bank in connection with NIM differ significantly from local banks which are classified in Book 1, Book 2, Book 3 and Book 4. Findings of LSD test are slightly different from the findings using the Tukey HSD, although both kind of tests states that the overall performance of Foreign Banks' NIM still lower than local banks'.

\begin{tabular}{|c|c|c|c|c|}
\hline & (I) Book & (J) Book & \begin{tabular}{|c|} 
Mean \\
Difference (I- \\
$\mathbf{J})$
\end{tabular} & Sig. \\
\hline \multirow{20}{*}{$\begin{array}{l}\text { Tukey } \\
\text { HSD }\end{array}$} & \multirow[t]{4}{*}{1.00} & 2.00 & .99686 & .409 \\
\hline & & 3.00 & -.04636 & 1.000 \\
\hline & & 4.00 & .18500 & 1.000 \\
\hline & & B_Foreign & $3.74200^{*}$ & .001 \\
\hline & \multirow[t]{4}{*}{2.00} & 1.00 & -.99686 & .409 \\
\hline & & 3.00 & -1.04322 & .793 \\
\hline & & 4.00 & -.81186 & .979 \\
\hline & & B_Foreign & $2.74514^{*}$ & .040 \\
\hline & \multirow[t]{4}{*}{3.00} & 1.00 & .04636 & 1.000 \\
\hline & & 2.00 & 1.04322 & .793 \\
\hline & & 4.00 & .23136 & 1.000 \\
\hline & & B_Foreign & $3.78836^{*}$ & .014 \\
\hline & \multirow[t]{4}{*}{4.00} & 1.00 & -.18500 & 1.000 \\
\hline & & 2.00 & .81186 & .979 \\
\hline & & 3.00 & -.23136 & 1.000 \\
\hline & & B_Foreign & 3.55700 & .172 \\
\hline & \multirow[t]{4}{*}{ B_Foreign } & 1.00 & $-3.74200^{*}$ & .001 \\
\hline & & 2.00 & $-2.74514^{*}$ & .040 \\
\hline & & 3.00 & $-3.78836^{*}$ & .014 \\
\hline & & 4.00 & -3.55700 & .172 \\
\hline \multirow[t]{20}{*}{ LSD } & \multirow[t]{4}{*}{1.00} & 2.00 & .99686 & .083 \\
\hline & & 3.00 & -.04636 & .958 \\
\hline & & 4.00 & .18500 & .894 \\
\hline & & B_Foreign & $3.74200^{*}$ & .000 \\
\hline & \multirow[t]{4}{*}{2.00} & 1.00 & -.99686 & .083 \\
\hline & & 3.00 & -1.04322 & .263 \\
\hline & & 4.00 & -.81186 & .567 \\
\hline & & B_Foreign & $2.74514^{*}$ & .005 \\
\hline & \multirow[t]{4}{*}{3.00} & 1.00 & .04636 & .958 \\
\hline & & 2.00 & 1.04322 & .263 \\
\hline & & 4.00 & .23136 & .883 \\
\hline & & B_Foreign & $3.78836^{*}$ & .002 \\
\hline & \multirow[t]{4}{*}{4.00} & 1.00 & -.18500 & .894 \\
\hline & & 2.00 & .81186 & .567 \\
\hline & & 3.00 & -.23136 & .883 \\
\hline & & B_Foreign & $3.55700^{*}$ & .027 \\
\hline & \multirow[t]{4}{*}{ B_Foreign } & 1.00 & $-3.74200^{*}$ & .000 \\
\hline & & 2.00 & $-2.74514^{*}$ & .005 \\
\hline & & 3.00 & $-3.78836^{*}$ & .002 \\
\hline & & 4.00 & $-3.55700^{*}$ & .027 \\
\hline
\end{tabular}

Post Hoc Test results using LSD test also show the performance of local banks' NIM did not show any significant difference. In accordance with the nominal amount of capital of each bank, it is possible that the average of net interest margins at each local banks book will vary nominally, however, the test results prove that the average of net interest margins in the percentage did not differ significantly. The research results showed that local banks with different magnitude of capital do not differ in their ability to produce NIM. Banks with larger capital are not more able to generate greater NIM. Empirical data also show that foreign banks have lower ability to produce NIM than local banks. The findings of this study indicate the success of the Indonesia Bank (BI) as the Indonesian banking regulatory authority to equate the performance of banks operating in Indonesia in managing their NIM. 


\section{CONCLUSION}

This study was undertaken to prove the public perception that bigger banks are more difficult to bankrupt than smaller banks through performance evaluation of Indonesian banks and foreign banks operating in Indonesia related to classification of capital.

The research results showed not found differences in the ability of banks with larger capital and also foreign banks with banks with smaller capital in managing their credit risk.

The research results showed that local banks with different magnitude of capital do not differ in their ability to produce NIM. Banks with larger capital are not more able to generate greater NIM. Empirical data also show that foreign banks have lower ability to produce NIM than local banks.

The results obtained indicate not enough evidence to conclude that bigger banks with higher core capital classification has better performance than smaller banks with lower core capital classification. Banks with more capital and also foreign banks are not more able to reduce their credit risk and also not show better ability to produce gains than local banks with smaller capital.

The findings of this study indicate the success of the Indonesia Bank (BI) as the Indonesian banking regulatory authority to equate the performance of banks operating in Indonesia in managing their NPL and also their NIM.

\section{REFERENCES}

[1] Abba, G. O., Zachariah, P., \& Inyang, E. E, Capital Adequacy Ratio and Banking Risks in the Nigeria Money Deposit Banks, Research Journal of Finance and Accounting, 2013, 4(17), p17-25, Available from http://www.iiste.org/Journals/index.php/RJFA/article/view/8972.

[2] Bank Indonesia, Peraturan Bank Indonesia No. 14/18/PBI/2012 tanggal 28-11-2012 tentang Kewajiban Penyediaan Modal Minimum Bank Umum, 2012, p2.

[3] Bank Indonesia, Surat Edaran BI No. 14/37/DPNP tgl 27 Desember 2012 tentang KPMM sesuai Profil Risiko, 2012, p1-3.

[4] Bank Indonesia, Peraturan Bank Indonesia No.13/1/PBI/2011 tanggal 5 Januari 2011 perihal Penilaian Tingkat Kesehatan Bank Umum, 2011, p4-5.

[5] Bank Indonesia, Surat Edaran BI No.13/23/DPNP tgl 25 Oktober 2011 perihal Penerapan Manajemen Risiko bagi Bank Umum, 2001, p2 - 3.

[6] Bank Indonesia, Surat Edaran BI No.13/24/DPNP tgl 25 Oktober 2011 perihal Penerapan Manajemen Risiko bagi Bank Umum, 2001, p2 - 4.

[7] Bank Indonesia, Peraturan Bank Indonesia No. 5/8/PBI/2003, 19 Mei 2003 sebagaimana diubah dengan PBI No. 11/25/PBI/2009, 1 Juli 2009; perihal Penerapan Manajemen Risiko bagi Bank Umum, 2009, p6-8.

[8] Infobank, Rating 120 Bank di Indonesia, Infobank, 2013; XXXV (411), p26-33.

[9] Bateni, Leila; Vakilifard, Hamidreza \& Asghari, Farshid, The Influential Factors on Capital Adequacy Ratio in Iranian Banks, International Journal of Economics and Finance, 2014; 6 (11), p108-116.

[10] Jeff, L, Capital adequacy: The benchmark of the 1990's. Bankers' Magazine, 1990, 173(1), p14-18. 